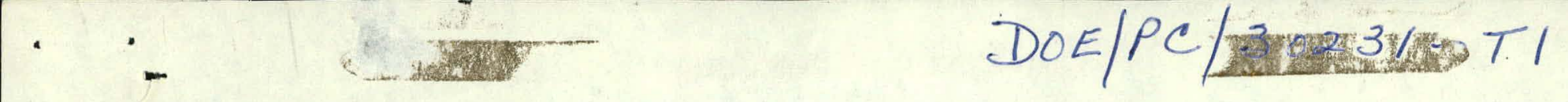

$a$ MASTER

\title{
SORBATE CHARACTERISTICS OF FLY ASH \\ SEMI ANNUAL PROGRESS REPORT
}

Grant 非 DE-FG22-80PC30231

Submitted by:

John W. Liskowitz

Principal Investigator

New Jersey Institute of Technology

323 High Street.

Newark, New Jersey 07102 


\section{DISCLAIMER}

This report was prepared as an account of work sponsored by an agency of the United States Government. Neither the United States Government nor any agency Thereof, nor any of their employees, makes any warranty, express or implied, or assumes any legal liability or responsibility for the accuracy, completeness, or usefulness of any information, apparatus, product, or process disclosed, or represents that its use would not infringe privately owned rights. Reference herein to any specific commercial product, process, or service by trade name, trademark, manufacturer, or otherwise does not necessarily constitute or imply its endorsement, recommendation, or favoring by the United States Government or any agency thereof. The views and opinions of authors expressed herein do not necessarily state or reflect those of the United States Government or any agency thereof. 


\section{DISCLAIMER}

Portions of this document may be illegible in electronic image products. Images are produced from the best available original document. 
This one year investigation is concerned with relating the sorbent characteristics of fly ash produced from test.coal obtained from 19.mines located in Virginia, West Virginia and Pennsylvania. Six of the test coals and their respective fly ashes have been sampled and boiler conditions monitored in P.S.E. \& G. coal fired boilers operated under minimum, intermediate and full power.

Major, minor and trace elemental analysis as well as Mössbauer spectra of three of the coals and their respective ashes have been completed. The atom composition of the surface of these fly ashes has also been determined by ESCA.

The $\mathrm{pH}$ and concentration of the major, minor and trace elements that leach out of the fly ash initially have been determined on the fly ashes produced from the Militant, Deep Hollow and Wellmore Cactus coals. All leachate samples to date exhibited an acidic pH. This leaching essentiajly ceases as the $\mathrm{pH}$ approached neutral conditions. This was found to occur after 4 liters of water was passed through each fly ash sample in a lysimeter.

The lysimetcr studies to define the sorbent characteristics of the fly ashes have not been completed yet. 
INTRODUCTION

A one year investigation which involves the joint efforts of New Jersey Institute of Technology and Public Service Electric and Gas Company is presently being carried out to identify the parameters (i.e. coal composition, boiler additives, combustion conditions, boiler types, oil/coal and natural gas/coal fuel ratios) that control the sorbent characteristics of the fly ash produced.

Earlier studies by the investigators identified two fly ashes with different sorbent characteristics that were repeatedly collected at different times from one of the coal fired boilers selected for this study. The reasons for the production of these different fly ashes could not be explained. However, when a neutral pH leachate, which contained the same cations and anions as found in fly ash leachate, was passed through a mixture of these two fly ashes contained in lysimeters, significantly greater removals of cations and anions occurred than was initially leached from these fly ashes separately. These findings indicate that the recycling of leachate from fly ash (after adjustment to neutral $\mathrm{pH}$ ) through a bed containing the proper mixture of fly ashes with desired sorbent characteristics can provide an inexpensive treatment of the toxic cations and anions which originally leached from fly ash in fly ash ponds or in landfill sites.

Four different types of coal fired boilers (Hudson, Mercer, Keystone and Commaugh) operated at full, intermediate and minimum power output following 'planned test procedures are producing the fly ash being investigated. The test procedure for the Hudson coal fired boiler is enclosed. It is representative of that which is followed for the other stations. The Hudson 
and Mercer coal fired boilers differ in that Hudson burns a high ash fusion coal and Mercer burns a lower ash fusion coal. Arrangements have been or are being made by P.S.E. \& G. during this investigation to have the coal delivered directly to the Hudson and Mercer generating stations from 19 mines located in Virginia, West Virginia and Pennsylvania (see Table 1) so that the sorbent characteristics of the fly ash produced by this coal can be related not only to coal composition but also to the mine source. The coal from these mines were selected for this study because they can provide the Hudson and Mercer generating stations with sufficient quantities of coal to carry out the planned test burns. Also, coal from 19 different mines should exhibit enough of variations in their composition so that the influence of coal composition on the sorbent characteristics of their respective fly ashes can be examined.

\section{Monitoring of Boiler Conditions and Collection of Samples for Analysis}

According to test procedures outlined on pages 17 and 18 , the temperature profile encountered in the boilers along with the coal, natural gas, and oil feed rates when co-fired, boiler additive feed rates, percent capacity of air flow into boiler, ambient air temperature and barometric pressure are monitored during maximum, intermediate and minimum power output (see Table 2). The flame temperatures in the bofler are measured with an optical pyrometer using the observation ports occupied by the T.V. cameras that are used to observe the flame conditions by station operating personnel. The gas temperatures in the boilers above the flame basket and in the region of the superheaters are measured by means of a water cooled thermocouple probe inserted through access ports located in the walls of the boiler. The gas and air inlet and outlet temperatures of the economizers 


\section{TABLE 1}

COAL SCHEDULED FOR COMBUSTION UNDER TEST CONDITIONS Hudson's coal flred boiler (high fusion coal)

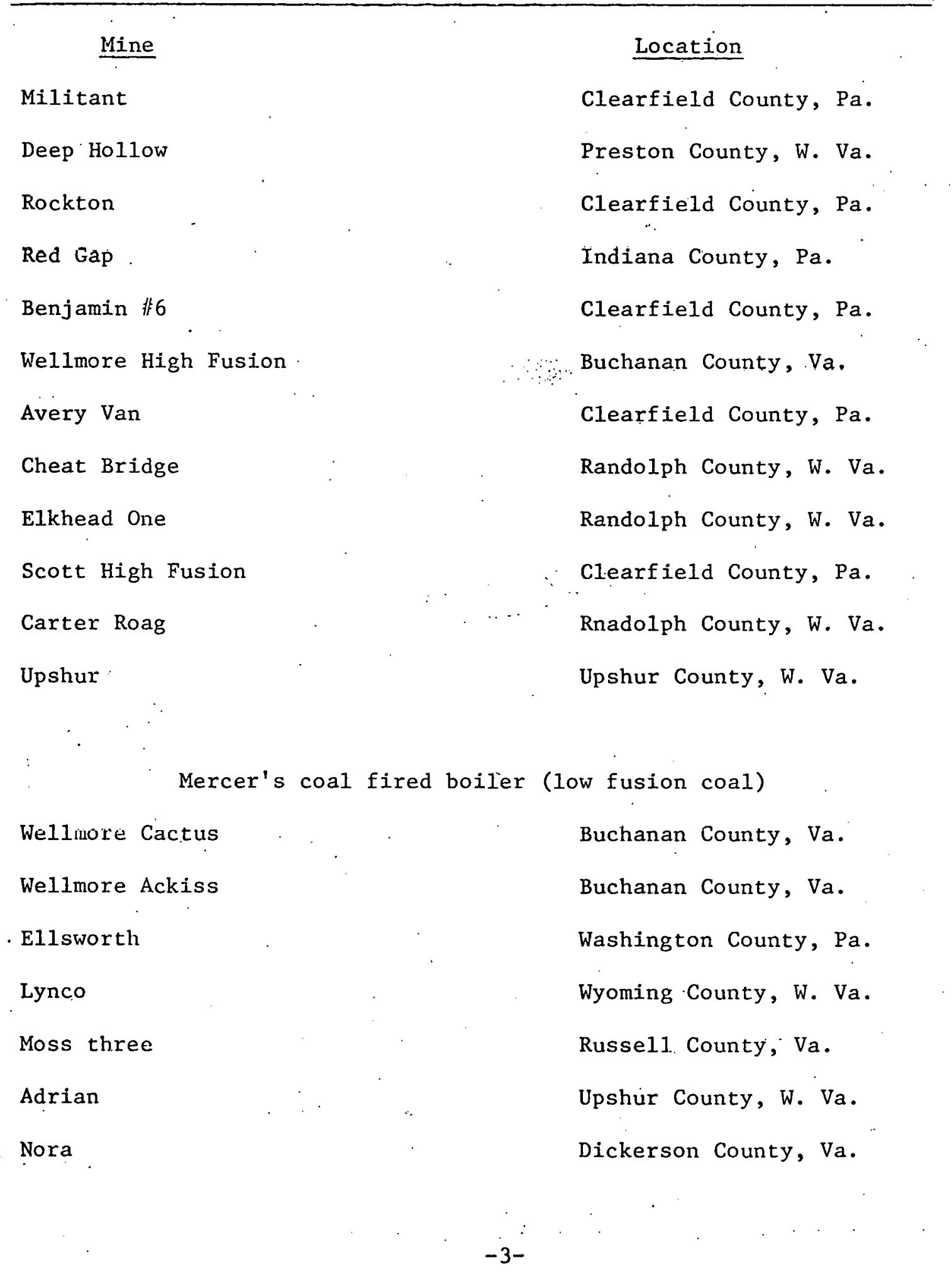




\section{TABLE 2}

Coa1 Combustion Conditions (Hudson)

Boller Temperatures $\quad$ Economizer Temperatures ${ }^{\circ} \mathrm{F}$

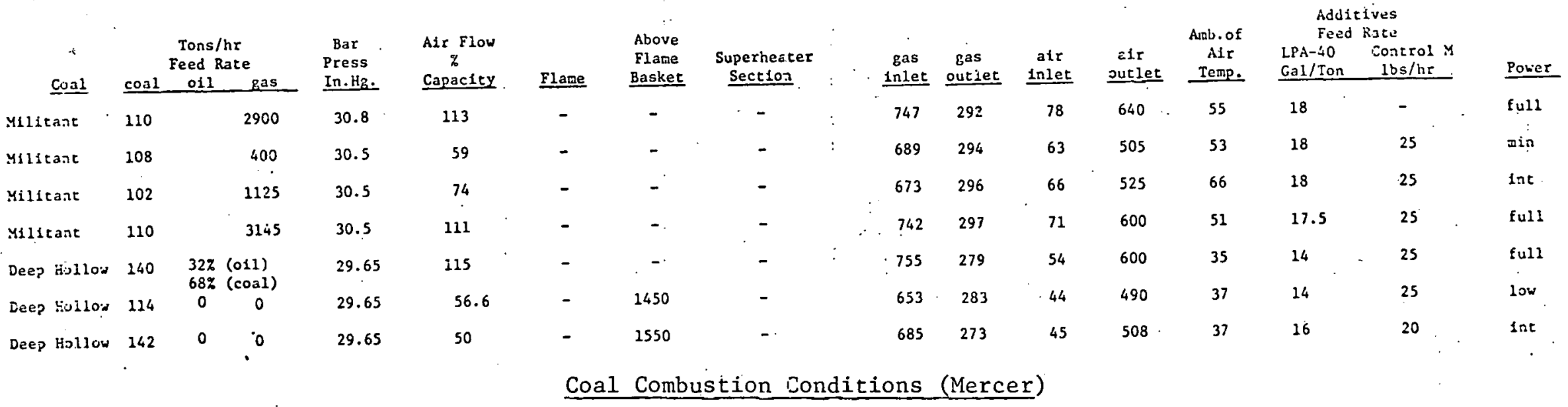

f

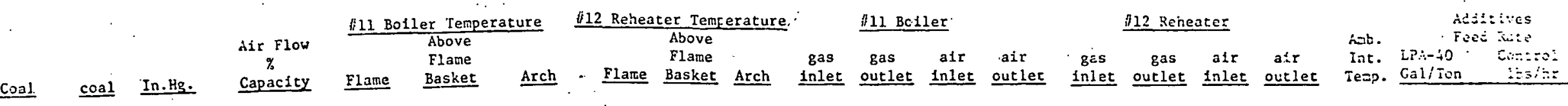

\begin{tabular}{|c|c|c|c|c|c|c|c|c|c|c|c|c|c|c|c|c|c|c|}
\hline $\begin{array}{l}\text { helinore } \\
\text { Cactus }\end{array}$ & 991 & 27.8 & 50 & 3125 & 1400 & 1680 & 2970 & 1400 & 1320 & 710 & 253 & 135 & 628 & 720 & 305 & 85 & 610 & 33 \\
\hline als:orth & 673 & 27.7 & 58 & 3100 & 1815 & 2240 & 3100 & 1740 & 1820 & 700 & 259 & 127 & 625 & 705 & 295 & 104 & 584 & 46 \\
\hline $\begin{array}{r}\text { relleoze } \\
\text { Ackiss }\end{array}$ & 546 & 27.8 & 42 & 2870 & 1590 & $1780^{\circ}$ & 2950 & 1620 & 1500 & 582 & 245 & ${ }^{161}$ & 529 & .576 & 243 & 78 & 505 & 56 \\
\hline $\begin{array}{l}\text { Wellmore } \\
\text { nckisiss }\end{array}$ & 862 & 27.8 & - & 3050 & 1900 & 2180 & 2950 & 1725 & 1500 & 690 & 253 & 116 & 510 & 698. & 263 & 79 & 698 & 56 \\
\hline ora & 905 & 27.94 & 60 & 3100 & 1850 & 2175 & 3250 & 1700 & 1700 & 655 & 223 & 120 & 575 & 635 & 270 & 65 & 555 & 34 \\
\hline
\end{tabular}


are routinely measured and recorded by the generating stations during the test burns.

During the combustion of the test coal, coal samples are collected at the entrance to each pulverizer that is in operation. The collection of fly ash and bottom ash samples are timed to correspond to the coal being burned. Different size distributions of the fly ash are obtained by collection of samples from both the front and back row of electrostatic precipitator hoppers. Bottom ash samples ran only be collected at the Mercer generating station. The Hudson coal fired boiler does not have a direct access to the bottom ash produced from a given coal that is being sampled and burned.

Analysis of Samples

$\underline{\text { Coal }}$

The coal samples are being analyzed for the complete major, minor, and trace elements, ash content, BTU content, sulfur and ash fusion temperatures according to ASTM Methods. The chemical forms of iron present in the coal and their respective ashes are being analyzed by Mössbauer spectroscopy.

\section{Fly Ash and Bottom Ash Samples}

The fly ash and bottom ash samples are being analyzed for the same major, minor and trace elements as found in the ashed coal samples. The results of these analysis are being compared to the surface composition of the fly ash as measured by ESCA to determine if there is a preferential concentration of specific elements at the surface of the fly ash particle which could influence its sorbent characteristics. A comparison of the Mössbauer results on the coal samples with those obtained on their. respective fly ash samples is being made. Oxides of iron in natural clay minerals 
have been reported (1) to be effective in the removal and retardation of As, $\mathrm{Cd}, \mathrm{Cr}, \mathrm{Cu}, \mathrm{Hg}, \mathrm{Ni}, \mathrm{Pb}, \mathrm{Sr}, \mathrm{V}$ and $\mathrm{Zn}$, all of which are encountered in leachates from solid waste landfill sites.

\section{Leaching and Sorbent Characteristics of Fly Ash}

The leaching properties of the fly ash of different sizes, collected from the front and rear electrostatic precipitator hoppers, are being determined. These determinations are being carried out by passing water through a lysimeter containing the fly ash sample and collecting and analyzing successive samples of effluent for $\mathrm{pH}$ and the major, minor and trace elements present in the original fly ash samples. Once the leaching of the major, minor, and trace elements cease, fly ash pond effluent collected from P.S.E. \& G. is passed through these $f l y$ ash samples in the lysimeters to determine their sorbent capacity for the major, minor; and trace elements. The sorbent capacity of the fly ash for the major, minor and trace elements present in the $f l y$ ash pond effluent and that originally leached from the fly ash samples is being determined by analyzing the fly ash pond effluent before and after it has passed through the fly ash samples until breakthrough is achieved for each of the elements.

Variations in coal composition, which can be traced to the mine of its origin, combustion conditions, volumetric air flow in boiler, presence or absence of boiler additives, and their types, boiler type, presence of oil or natural gas cofired with the coal, will then be correlated with the sorbent capacity of the fly ashes. 


\section{RESULTS}

Originally it was proposed that the sorbent characteristic of the fly ash produced from the coal burned in the Hudson coal fired boiler be initially examined. Unfortunately, cold weather and ice this past winter slowed delivery of the test coals from the mines especially to the Hudson generating station. As a result, the test coals, their fly ashes and buttom ashes have been collected from the Hudson and Mercer generating stations: The Militall aud Deep Hollow high fusion coals and their fly ashes produced under minimum, intermediate and full loads have been collected at the Hudson generating station. The fly ashes produced at full load with the Militant coal and Deep Hollow coal (see Table 1) was obtained by cofiring it with natural gas and oil, respectively (see Table 2). The limited results on the boiler temperatures monitored during the combustion of the Deep Hollow and Militant coal at the Hudson generating station was due to the fact that our water cooled thermocouple probes were being modified during this period of collection to fit the access ports in P.S.E. \& G. boilers. The fly ash produced with the Militant and Deep Hollow coals at intermediate and minimum loads was obtained by operating the boiler at a maximum coal feed rate with no supplementing fuel and at reduced coal feed rate respectively (see Table 2). Comparison of the sorbent characteristic of the fly ashes produced at intermediate and minimum load should indicate the effect of boiler gas temperature on the sorbent characteristics since the same coal without supplemental fuel is being burned but at different rates. Comparison of the sorbent characters of the fly ashes produced at full- loads with those produced at intermediate loads should provide the effect of cofiring oil and natural gas with coal on the sorbent characteristics. 
The Wellmore Cactus, Wellmore Ackiss, Ellsworth and Nora low fusion coals, their fly ashes and bottom ashes have been collected at the Mercer generating station (see Table 1). However, because of the power demands imposed upon the Mercer generating station, the station was only able to follow the planned test procedures during the burning of the Wellmore Ackiss coal. As a result, samples of fly ashes and bottom ashes produced at minimum and maximum load were only obtained to-date with this one coal. Samples of fly ash and bottom ash from the Wellmore Cacuts, Ellsworth and Nora coals. worc collected al illaxlmum load.

\section{Analysis of Coal and Ash Samples}

Analysis of all test coals collected for carbon, sulfur, ash, and BTU content on a dry basis as well as the ash fusion temperatures have been performed (see Table 3).

The determination of ash fusion temperatures will. allow us to determine how the sorbent characteristics of the fly ash particles are influenced by their being either in the molten or solid state above the flame basket in the Mercer and Hudson coal fired boilers, respectively. The temperatures that we have measured in the arch above the flame basket in the Mercer coal fired boiler are generally in the temperature range above $2100^{\circ} \mathrm{F}$ (see Table 3). These temperatures are sufficient to maintain the ash particles in a molten state. The temperatures measured to-date above the flame basket in the Hudson coal fired boiler are well below the temperatures where the ashes is molten. Thus, the ash particles above the flame basket in the Mercer coal fired boiler should remain in the molten state in contact with the gas for longer periods of time than in the Hudson coal fired boiler. 
TABLE 3

Militant Coal (Hudson)

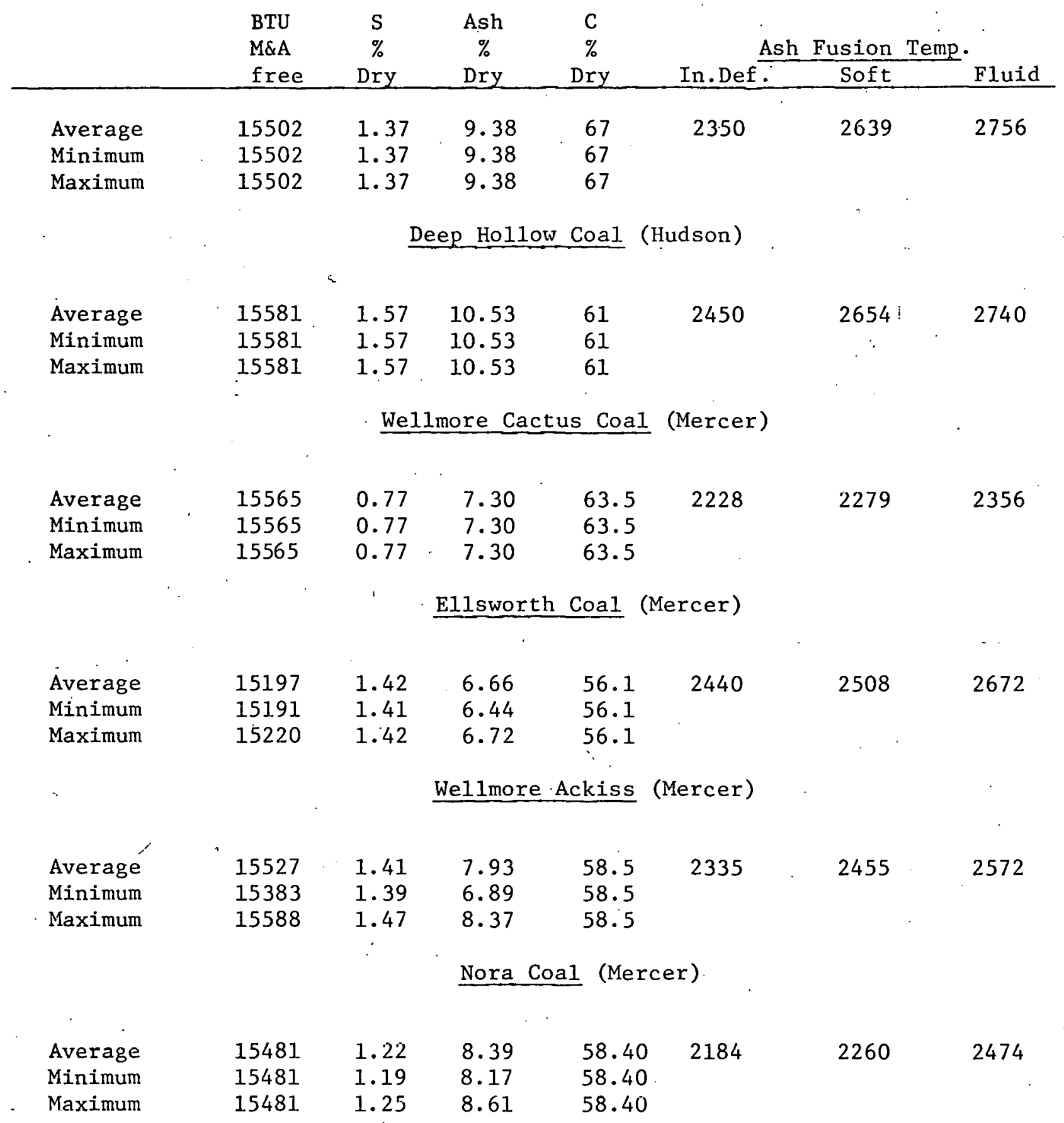


Analysis of the major, minor and trace elements consisting of $\mathrm{Ca}$, $\mathrm{Mg}$, $\mathrm{Si}, \mathrm{Al}, \mathrm{Fe}, \mathrm{Mn}, \mathrm{Zn}, \mathrm{K}, \mathrm{Na}, \mathrm{Ti}, \mathrm{Cd}, \mathrm{Sn}, \mathrm{Mo}, \mathrm{Ni}, \mathrm{Pb}, \mathrm{Cu}, \mathrm{Cr}$, in the Militant, Deep Hollow and Wellmore Cactus coals and their respective ashes have been. completed. Analysis for $\mathrm{As}, \mathrm{Hg}, \mathrm{Sb}, \mathrm{Se}, \mathrm{F}, \mathrm{Cl}$, and $\mathrm{SO}_{3}$ in the coals and their respective ashes have yet to be done.

Analysis using E.S.C.A. to determine the atomic composition of the surfaces of the ashes produced from the Militant, Deep Hollow and Wellmore Cactus coals for the different load levels have been complctcd. Also, the Mössbauer spectra of the iron compounds in the Militant, Deep Hollow and We11more Cactus coals and their respective ashes have been done.

Mössbauer spectroscopy has been found to provide a good probe of $f 1 y^{\prime}$ ash $(2,3,4)$. This technique can help to determine the symmetry and the jonic state of iron in many solids (5). Also, Mössbauer spectroscopy, in conjunction with $x$-ray diffraction, has been used to determine the iron compounds present in fly ash $(2,3)$.

The computer interface between the E.S.C.A. and the Univac at N.J.I.T.'s computer center has been extended to include the Mössbauer spectrometer by using an Apple computer as the interface. The hardware part of both the Mössbauer spectrometer and the E.S.C.A. interfaces have been completed. However, the software part of the E.S.C.A. interface is still being completed.

The Mössbauer spectrum of the Wellinore Cactus coal (low fusion) is consistant with two quadrupole split iron species (see Figure 1). The Mössbauer spectrum of the Deep Hollow (high fusion) coals is consistent with one quadrupole split iron species (see Figure 3 ). Although the computer analysis is not complete at this time, pyrite appears to be present in both coals, while the Mercer coal also appear to have 
ferrous sulfate. This must be confirmed by a complete analysis of the data.

The fly ash spectra are more complex (see Figures 2 and 4) and an interpretation of this data must be done by computer. The fly ash from the high fusion coals have the more complex pattern (see Figure 4). The large spread of the spectra indicates that a species with a magnetic field is present. The large number of quadrupole split patterns observed also indicate the presence of both ferric and fcrrous species. A cumputer analysis is in progress. The fly ash samples from low fusion coal give a simple pattern in their Mössbauer spectra (see Figure 2). There is very little magnetic species present in this fly ash. Also, the iron appears to be in a more oxidized form in the low fusion fly ash.

The analysis of the Mössbauer data must await further computer fitting of the data. At this time, there are significant changes in the Mössbauer pattern for the various fly ash samples, particularly between samples from low fusion coal and high fusion coal. Molssbauer spectroscopy appears to reflect the thermal history of the coal in the boiler. This must be confirmed and possible correlation with leaching and sorption characteristic determined.

Leaching studies, as described earlier using the fly ash samples of different sizes produced by the Militant, and Deep Hollow coals, have been carried out. Analysis of successive lysimetcr effluent samples for $\mathrm{pH}$ and the above major, minor and trace elements found in the ashes produced from the Militant and Deep Hollow coals for different boiler load levels have been carried out until the leaching of the elements has essentially ceased. 


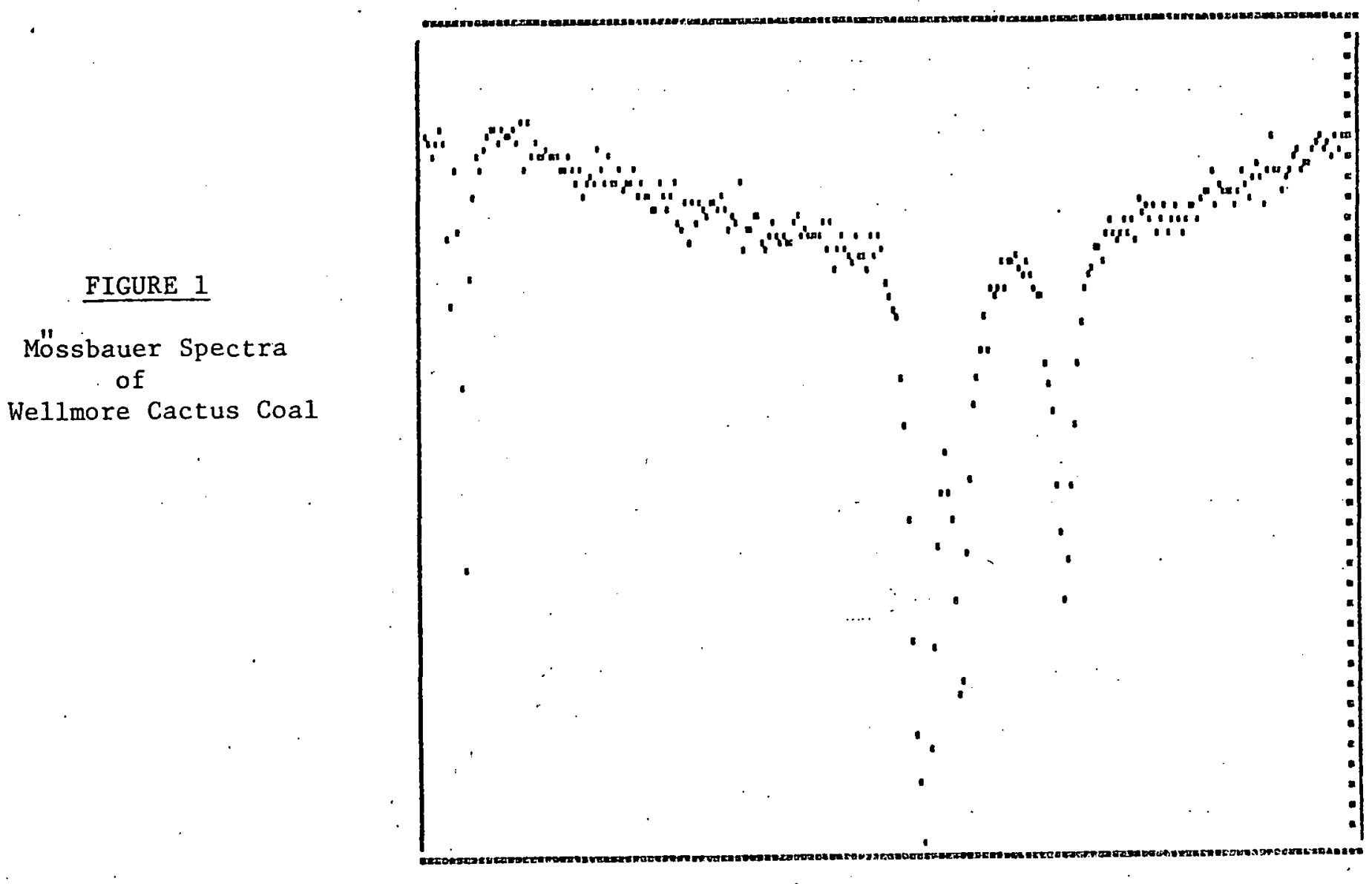

\section{FIGURE 2}

Mössbauer. Spectra of

Wellmore Cactus Fly Ash

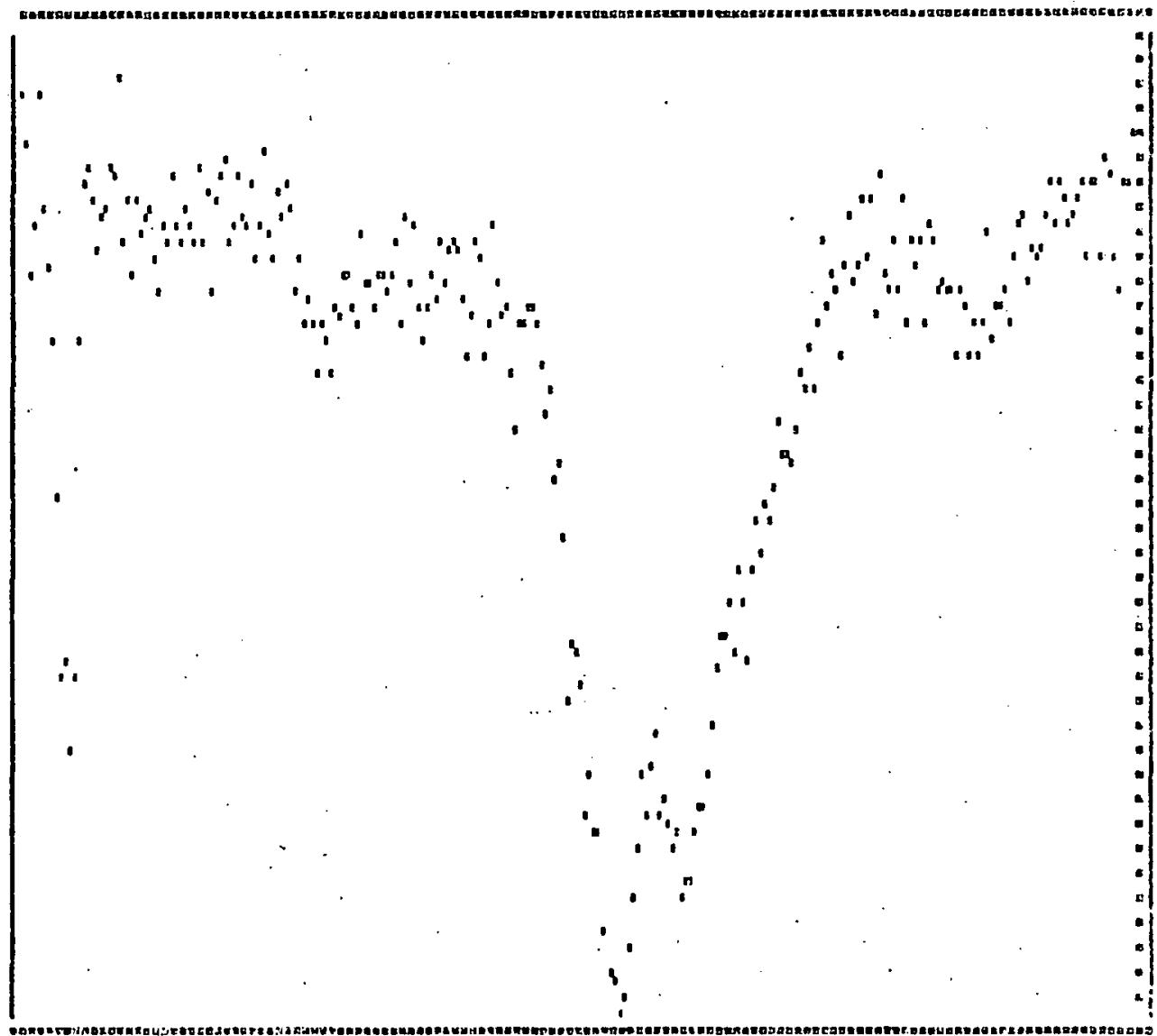


FIGURE 3

Mössbauer Spectra of Deep Hollow Coal

FIGURE 4

Mössbauer Spectra Deep Hollow Fly Ash
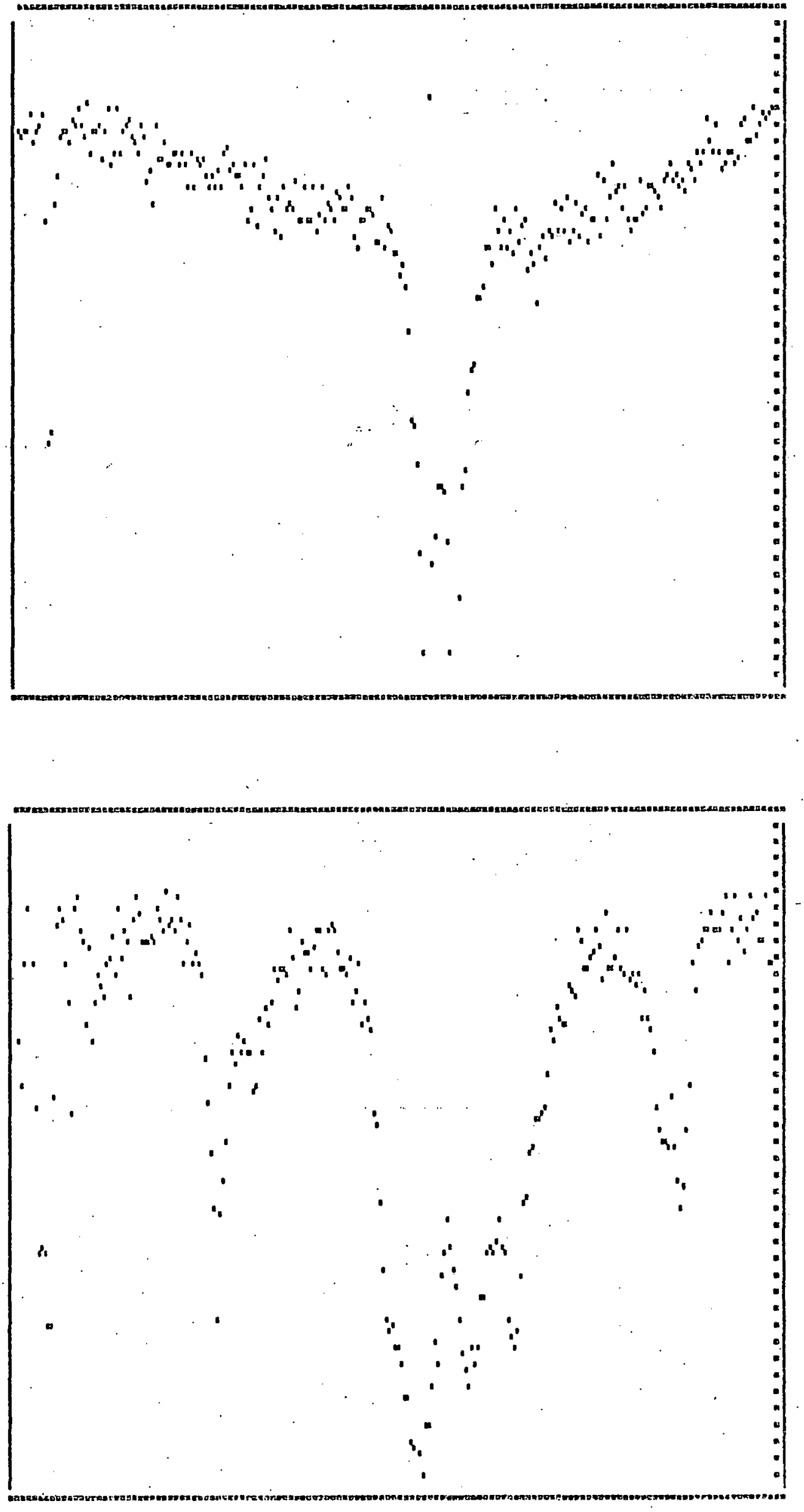

$-13-$ 
The initial leachate effluent collected from the lysimeter containing the fly ashes produced from the Militant and Deep. Hollow test coals in the Hudson coal fired boiler were all acidic ( $\mathrm{pH}$ range 3.5 to 4.0). However, the leachate approached neutral $\mathrm{pH}$ after about 4 liters of water had been passed through the fly ash samples.

The concentrations of the initial leachate effluent collected were found to range from $40 \mathrm{mg} / 1$ to $650 \mathrm{mg} / 1$ for major elements ( $\mathrm{Si}, \mathrm{Al}, \mathrm{Fe}, \mathrm{Ca}$, $\mathrm{Mg}, \mathrm{K}, \mathrm{Na}$ ), $0.05 \mathrm{mg} / 1$ to $4.0 \mathrm{mg} / 1$ tor minor elements ( $\mathrm{Ti}, \mathrm{Mn}$ ), and $0.30 \mathrm{mg} / 1$ to $25 \mathrm{mg} / 1$ for trace elements (Cd, B, $\mathrm{Sn}, \mathrm{Ni}, \mathrm{Pb}, \mathrm{Mo}, \mathrm{Cu}, \mathrm{Cr}$ ). However, analysis of the successive leachate samples show that the conccntration in the leachate decreased from $0 \mathrm{mg} / 1$ to $10 \mathrm{mg} / 1$ for major elements, $0 \mathrm{mg} / 1$ to $0.030 \mathrm{mg} / 1$ for minor elements, and $0 \mathrm{mg} / 1$ to $0.20 \mathrm{mg} / 1$ for trace elements as the $\mathrm{pH}$ of the leachate approached neutral conditions.

In-depth evaluation and comparison of the results of the various analysis have not been carried out since none of the lysimeter experiments which characterize the sorbent properties of the fly ash samples have been completed. 


\section{REFERENCES}

1. Fuller, W., McCarthy, C., Alesii, B. A., and Niebla, E. "Liners for Disposal Sites to Retard Migration of Pollutants from Solid Waste Landfill Sites", Residual Management by Land Disposal, EPA 600/9/76.

2. Saporoschenko, M., Hinckley, C., Smith, G. V., Twardowska, H., Shiley, R. H., Griffin, R. A., and Russell, S. J. "Fuel", 59, 1980, 566.

3. 'Griffin, R. A., Schuller, R. M., Suloway, J. J., Shimp, N. F., Childers, W. F., and Shiley, R. H. "Chemical and Biological Characterization of Leachates from Coal Solid Wastes", Environmental Geology Notcc 89, November 1980, Illinois Institute of Natural Resources, State Geological Survey Division, Champaign, Illinois.

4. Hinckley, C., Smith, G. V., Twardowska, H., Saporoschenko, M., Shiley, R. H., and Griffin, R. A. "Fuè1", 1980, 59, 161.

5. Bancroft, G. M. "Mössbauer Spectroscopy - An Introduction for Inorganic Chemists and Geochemists", John Wiley and Sons, New York, 1973. 
EVALUATION PLAN

TEST COAL BURN

HUDSON NO. 2

The primary objective of this plan is to provide a uniform procedure to evaluate test coals for Hudson No. 2. The following conditions should exist prior to the test burn:

1. Minimum of 3 barges or 7,000 tons of test coal available.

2. Minimum of four pulverizers available.

3. Two days notice prior to coal receipt.

4. Supplemental fuel, oil or gas, available.

5. Condition of furnace, burners, registers, and igniters should be normal.

6. Coal flow on three burner mills will, he limited to $80 \%$.

7. Test to start with a normal deslagging load drop.

8. Steady load conditions for high load test period (maximum of 42 hours).

The following test schedule shall be followed:

1. Two days prior to arrival of the test coal barges, burn down completely a minimum of four reclaim hoppers.

2. Unload and place the test coal over the four empty hoppers.

3. Any remaining test coal should be left in the barge and used to top off the hoppers after the test begins.

4. Set the plow so that only test coal will be supplied to the silos.

5. Begin supplying test coal to the sllos 5 hours prior to the deslagging load drop. This will be 2300 hours for a deslagging load period to start at 0400 hours and end at 0600 hours.

6. Blow soot during load drop to $275 \mathrm{Mw}$ net with 4 or 5 mills in service.

7. Hold $275 \mathrm{Mw}$ net load for 2 hours with flue gas oxygen between 6 to $8 \%$, windbox differential at approximately 1 inch $\mathrm{H}_{2} \mathrm{O}$, registers in full load position, igniters out of service, and furnace televisions in service. Observe furnace wall conditions for complete deslagging as wel. as burner and furnace flame stability. 
8. Increase load to maximum coal burning capability with no supplemental fuel being fired and hold for two hours for observations.

9. Raise load to maximum attainable by firing supplemental fuel to replace unavailable pulverizers, adjust registers for optimum position, hold flue gas oxygen at $4 \%$, and stabilize main and reheat steam temperatures. Sootblowing is to be done twice per shift.

10. Hold load for duration of test coal supply, record operating data, and continue to observe furnace conditions every two hours paying particular attention to slagging conditions on front and rear walls as well as the slope. Total estimated time period that unit will be at full load will depend upon mill availability:

42 hours for 4 mill operation

38 hours for 5 mill operation

31 hours for 6 mill operation

11. If furnace conditions are satisfactory, reduce the flue gas oxygen to $3 \%$ when the reclaim hoppers begin to run out of test coal. Continue to hold load, record data, and observe furnace conditions until test coal is exhausted.

12. While sootblowing, reduce load to $300 \mathrm{Mw}$ and hold normal conditions for a deslagging period. Observe furnace wall conditions for complete deslagging.

13. All data should be noted on the attached data sheet and comments made on the appropriate form. 
MAR 16 TSE:-

\section{THIS PAGE}

\section{WAS INTENTIONALLY LEFT BLANK}

